\title{
Pengaruh Kompensasi, Kompetensi, dan Motivasi Terhadap Kinerja Dosen di STMIK Royal Kisaran
}

\author{
Pristiyanilicia Putri \\ Sekolah Tinggi Manajemen Informatika dan Komputer Royal Kisaran, Indonesia \\ Email : pristiyanilicia@gmail.com
}

\begin{abstract}
Abstrak
Penelitian ini bertujuan untuk mengetahui pengaruh kompensasi, kompetensi, dan motivasi secara parsial dan secara simultan terhadap kinerja dosen STMIK Royal Kisaran Kabupaten Asahan Sumatera Utara. Metode penelitian yang dipakai pada penelitian ini menggunakan metode kuantitatif dimana instrument pengumpulan data yang digunakan berupa angket atau kuesioner, serta wawancara. Data diperoleh dari populasi dosen tetap yang ada pada kampus STMIK Royal Kisaran pada tahun 2019 yaitu sebanyak 90 orang dosen. Teknik pengambilan sampel yang digunakan adalah sampling jenuh sehingga sampel dalam penelitian ini adalah seluruh dari populasi yang diambil yang berjumlah 90 responden. Sedangkan metode analisis yang digunakan menggunakan analisis regresi berganda dengan melakukan uji $\mathrm{F}$ dan uji t dimana data diolah menggunakan bantuan software SPSS Versi 20.0. Dari hasil analisis regresi berganda diperoleh persamaan $\mathrm{Y}=1,497+0,301 \mathrm{X}_{1}$ $+0,310 \mathbf{X}_{2}+0,067 \mathbf{X}_{3}$. Secara simultan variabel kompensasi, kompetensi, dan motivasi berpengaruh terhadap variabel kinerja dosen. Namun secara parsial hanya variabel kompensasi dan kompetensi saja yang berpengaruh terhadap variabel kinerja dosen, sedangkan variabel motivasi tidak berpengaruh secara parsial terhadap variabel kinerja dosen di STMIK Royal Kisaran.
\end{abstract}

Kata kunci: Kompensasi; Kompetensi; Motivasi; Kinerja Dosen; metode penelitian kuantitatif.

\section{PENDAHULUAN}

Dosen merupakan salah satu komponen terpenting pada sebuah sistem pendidikan di perguruan tinggi. Peran, tugas, dan tanggung jawab dosen sangat penting dalam mewujudkan tujuan pendidikan nasional, yaitu mencerdaskan kehidupan bangsa, meningkatkan kualitas manusia Indonesia yang meliputi kualitas iman/takwa, akhlak mulia, dan penguasaan ilmu pengetahuan, teknologi, dan seni, serta mewujudkan masyarakat Indonesia yang maju, adil, makmur, dan beradab. Untuk melaksanakan fungsi, peran, dan kedudukan yang sangat strategis tersebut diperlukan dosen yang professional (Pristiyanilicia, 2018). Dosen berperan aktif dalam menetapkan rencana, sistem, proses, dan tujuan yang ingin dicapai. Keberhasilan dosen dalam organisasi erat kaitannya dengan kinerja.

Kinerja merupakan hasil pekerjaan yang mempunyai hubungan kuat dengan tujuan strategis organisasi, kepuasan konsumen, dan memberikan kontribusi pada ekonomi serta melakukan pekerjaan dan hasil yang dicapai dari pekerjaan tersebut. Dapat diartikan bahwa kinerja dosen adalah perilaku nyata yang ditampilkan seorang dosen sebagai prestasi kerja yang dihasilkan sesuai perannya sebagai tenaga fungsional akademik (Wibowo, 2012). Indikator kinerja dosen dapat dinilai dari hasil kerja pada tridharma perguruan tinggi yaitu bidang pendidikan dan pengajaran, bidang penelitian, dan bidang pengabdian pada masyarakat.

STMIK Royal Kisaran merupakan sebuah institusi perguruan tinggi swasta yang menyelenggarakan pendidikan tinggi bermutu, inovatif, adaftif, dan futuristik dibidang teknologi informasi serta memfasilitasi dan membina program studi dalam kegiatan penelitian yang sesuai dengan perkembang IPTEK dibidang teknologi informasi (Pristiyanilicia, 2018).

Banyak faktor yang dapat mempengaruhi kinerja seorang dosen, beberapa diantaranya berasal dari dosen itu sendiri yang disebut dengan faktor internal seperti pengetahuan, manajemen diri, disiplin, tanggungjawab, akuntabilitas, motivasi kerja, sikap, kepribadian dan lain-lain. Sementara itu faktor dari luar atau eksternal seperti gaya kepemimpinan, pelatihan, kompensasi, kompetisi, budaya organisasi dan lain-lain (Sri Astuti, 2014). Dari hasil wawancara dengan beberapa orang dosen dan dari data LPPM STMIK Royal menunjukkan bahwa kinerja dosen belum menunjukkan hasil yang 
maksimal dari bidang penelitian dan pengabdian masyarakat dimana masih belum proposionalnya hasil karya ilmiah dan PKM dengan jumlah dosen yang ada serta biaya yang disediakan oleh pihak Institusi masih rendah. Sehingga dengan kondisi tersebut mengakibatkan rendahnya kompetensi, kompensasi, serta motivasi dosen dalam mencapai kinerja tersebut. Dengan demikian, maka pada penelitian ini akan dilihat faktor kompensasi, kompetensi, dan motivasi kerja sejauh mana ke tiga faktor tersebut mempengaruhi kinerja dosen di STMIK Royal Kisaran.

Berdasarkan penjelasan sebelumnya, maka rumusan masalah pada penelitian ini adalah sebagai berikut (1) Apakah kompensasi berpengaruh terhadap kineja dosen STMIK Royal?, (2) Apakah kompetensi berpengaruh terhadap kineja dosen STMIK Royal?, (3) Apakah motivasi berpengaruh terhadap kinerja dosen STMIK Royal?, (4) Apakah kompensasi, kompetensi, dan motivasi secara simultan (bersama-sama) berpengaruh terhadap kinerja dosen STMIK Royal?

\section{TINJAUAN LITERATUR}

\subsection{Kinerja Dosen}

\section{Pengertian Kinerja Dosen}

Kinerja adalah performace atau unjuk kerja yang dapat diartikan juga prestasi kerja atau pelaksanaan kerja atau hasil unjuk kerja. Kinerja merupakan keberhasilan seseorang atau kelompok orang dalam melaksanakan tugas dan tanggung jawabnya serta kemampuan untuk mencapai tujuan dan standar yang telah ditetapkan. Kinerja merupakan salah satu aspek terpenting dalam sebuah organisasi. Seorang dosen yang memiliki prestasi kerja yang bagus, maka dia cenderung sebagai pegawai yang memiliki kinerja yang baik (Wibowo, 2016).

Dengan demikian dapat disimpulkan bahwa kinerja dosen adalah kemampuan yang ditunjukkan oleh dosen dalam melaksanakan tugas atau pekerjaannya. Kinerja dikatakan baik dan memuaskan apabila hasil yang dicapai sesuai dengan standar yang telah ditetapkan.

\section{Faktor-faktor yang mempengaruhi kinerja Dosen}

Menurut Rachmawati (2013) keberadaan dosen dalam melaksanakan tugas dan kewajibannya tidak lepas dari pengaruh faktor internal maupun faktor eksternal yang membawa dampak pada perubahan kinerja dosen. Faktor-faktor yang mempengaruhi kinerja dosen yaitu antara lain Kepribadian dan dedikasi, Pengembangan profesi, Kemampuan mengajar, Antar hubungan dan komunikasi, Hubungan dengan masyarakat, Kedisiplinan, Kesejahteraan, dan Iklim kerja.

\section{Indikator-indikator kinerja Dosen}

Sebagai pendidik, dosen mengemban tugas dan tanggung jawab untuk mendidik. Mereka memikul tanggung jawab individual dan kolektif. Tanggung jawab individual adalah tanggung jawab secara akademik. Sedangkan tanggung jawab kolektif adalah tanggung jawab selaku senat perguruan tinggi. Tugas dan tanggung jawab dosen tidak hanya sebagai pendidik dan peneliti tetapi juga berperan sebagai penyebar informasi dan agen pembaharuan, yang mana sejalan dengan fungsi perguruan tinggi sebagai lembaga pendidikan. Tugas dan tanggung jawab dosen yang diamanatkan dalam Tridharma Perguruan Tinggi mencakup: pendidikan dan pengajaran, penelitian dan kegiatan pengabdian kepada masyarakat (Peraturan Pemerintah Nomor 60 tahun 1999 tentang Perguruan Tinggi).

\subsection{Kompensasi \\ Pengertian Kompensasi}

Menurut Mangkunegara (2016) salah satu fungsi yang penting dalam manajemen sumber daya manusia (MSDM) itu adalah kompensasi. Kompensasi merupakan salah satu aspek yang paling sensitif di dalam hubungan kerja. Di zaman modern saat ini, telah ada kasus yang terjadi dalam hubungan kerja yang mengandung masalah kompensasi dan berbagai segi yang terkait, seperti tunjangan, kenaikan kompensasi, struktur kompensasi, dan skala kompensasi. Dalam praktiknya masih banyak perusahaan yang belum memahami secara benar sistem kompensasi. Padahal sistem 
kompensasi dapat membantu perusahaan di dalam memberi penguatan terhadap nilai-nilai kunci organisasi serta memfasilitasi pencapaian tujuan organisasi.

\section{Tujuan Pemberian Kompensasi}

Adapun tujuan dari manajemen kompensasi antara lain: Memperoleh personel berkualitas, Mempertahankan karyawan yang ada, Memastikan keadilan, Menghargai perilaku yang diinginkan, Mengawasi biaya, Mematuhi peraturan, Memfasilitasi pengertian, Meningkatkan Efisiensi administrasi (Sri Astuti, 2014)

\section{Jenis-jenis dan Indikator kompensasi}

Berikut ini ada beberapa jenis kompensasi yang terdiri dari (I'tidal, M., \& Jam'an, A. (2016):

1) Kompensasi Financial

a. Kompensasi Langsung seperti Bayaran Pokok (Base Pay) yaitu gaji dan upah, Bayaran Prestasi (Merit Pay), Bayaran Insentif (Insentive Pay) yaitu bonus, komisi, pembagian laba, pembagian keuntungan, dan pembagian saham., Bayaran Tertangguh (Deferred Pay) yaitu program tabungan, dan anuitas pembelian saham.

b. Kompensasi Tidak Langsung seperti Program perlindungan yaitu asuransi kesehatan, asuransi jiwa, pensiun, dan asuransi tenaga kerja, Bayaran di luar jam kerja yaitu liburan, hari besar, cuti tahunan, dan cuti hamil, Fasilitas yaitu kendaraan, ruang kantor, tempat parkir dan lainnya.

2) Kompensasi Non Financial

Kompensasi non financial adalah segala bentuk penghargaan yang diberikan oleh perusahaan dalam bentuk bukan financial atau bukan uang. Adapun kompensasi non financial mencakup: Lingkungan kerja dan Pekerjaan

Berdasarkan dari jenis-jenis kompensasi di atas, maka indikator variabel kompensasi dari penelitian ini adalah konpensasi langsung dan tidak langsung.

\subsection{Kompetensi}

\section{Pengertian Kompetensi}

Kompetensi adalah seperangkat pengetahuan, keterampilan, dan nilai-nilai dasar yang direfleksikan dalam kebiasaan berpikir dan bertindak. Kompetensi juga dapat didefenisikan sebagai spesifikasi pengetahuan, keterampilan dan sikap yang dimiliki seseorang serta penerapannya di dalam pekerjan, sesuai dengan standar kinerja yang dibutuhkan oleh masyarakat dan dunia kerja (Wibowo, 2016). Kompetensi merupakan karakteristik yang mendasar pada setiap individu yang dihubungkan dengan kriteria yang direferensikan terhadap kinerja yang unggul atau efektif dalam sebuah pekerjaan atau situasi. Kompetensi merupakan landasan dasar karakteristik orang dan mengindikasikan cara berperilaku atau berpikir, menyamakan situasi, dan mendukung periode waktu cukup lama. Terdapat lima tipe karakteristik kompetensi, yaitu Motif, Sifat, Konsep diri, Pengetahuan, dan Keterampilan (Wibowo, 2016).

\section{Indikator Kompetensi Dosen}

Adapun kompenen-kompenen kompetensi yang harus dimiliki oleh pendidik antara lain:

Performance component, The teaching Subject Component, The teaching Process Component, The Personal adjustment component, The teaching profesional component, Attitude component (Hasibuan, 2016). Menurut Peraturan Menteri Pendidikan Nasional Republik Indonesia Nomor 16 Tahun 2007 Tentang Standar Kualifikasi Akademik dan Kompetensi Guru, adapun macam-macam kompetensi yang harus dimiliki oleh tenaga guru antara lain: kompetensi pedagogik, kepribadian, profesional dan sosial yang diperoleh melalui pendidikan profesi yang menjadi indikator dari variabel kompetensi pada penelitian ini. 


\subsection{Motivasi}

\section{Pengertian Motivasi}

Seseorang yang tidak termotivasi, hanya memberikan upaya minimum dalam hal bekerja. Konsep motivasi, merupakan sebuah konsep penting studi tentang kinerja individual. Dapat juga dikatakan bahwa motivasi adalah faktor yang mendorong orang untuk bertindak dengan cara tertentu.

Menurut Mangkunegara (2016) motivasi terbentuk dari sikap (attitude) karyawan dalam menghadapi situasi kerja di perusahaan (situation). Motivasi merupakan kondisi atau energi yang menggerakkan diri karyawan yang terarah atau tertuju untuk mencapai tujuan organisasi perusahaan. Sikap mental karyawan yang pro dan positif terhadap situasi kerja itulah yang memperkuat motivasi kerjanya untuk mencapai kinerja maksimal.

\section{Tujuan Motivasi}

Adapun tujuan Motivasi menurut Hasibuan (2016) yaitu : Meningkatkan moral dan kepuasan kerja karyawan, Meningkatkan produktivitas kerja karyawan, Meningkatkan kedisiplinan karyawan, Mempertahankan kestabilan karyawan perusahaan, Mengefektifitaskan pengadaan karyawan, Menciptakan suasan dan hubungan kerja yang baik, Meningkatkan loyalitas, kretivitas dan partisipasi karyawan, Meningkatkan tingkat kesejahteraan karyawan, Mempertinggi rasa tanggung jawab karyawan terhadap tugas - tugasnya, Meningkatkan efisiensi penggunaan alat-alat bahan baku.

\section{Faktor-faktor yang Mempengaruhi Motivasi Kerja}

Berikut ini ada faktor-faktor yang mempengaruhi orang bekerja secara umum, yaitu :

1) Faktor Internal: persepsi individu mengenai kebutuhan diri sendiri, keinginan dan harapan dari individu seperti perasaan berprestasi, pengakuan, perasaan kebebasan, dan sikap terhadap pekerjaan.

2) Faktor Eksternal: gaji, promosi, perlakuan rekan kerja, jenis dan sifat pekerjaan, situasi lingkungan, Sistem imbalan yang diterima.

\section{Indikator motivasi kerja}

Dari penjelasan mengenai definisi, tujuan, dan faktor-faktor yang mempengaruhi motivasi, maka indikator variabel motivasi pada penelitian ini adalah kebutuhan akan prestasi, kebutuhan akan afiliasi, dan kebutuhan akan kekuasaan.

\subsection{Kerangka Berfikir}

Dari penjelasan sebelumnya untuk lebih memudahkan pemahaman dalam mempelajari dan melakukan penganalisaan, maka dapat dibuat kerangka pikiran dalam skema berikut ini:

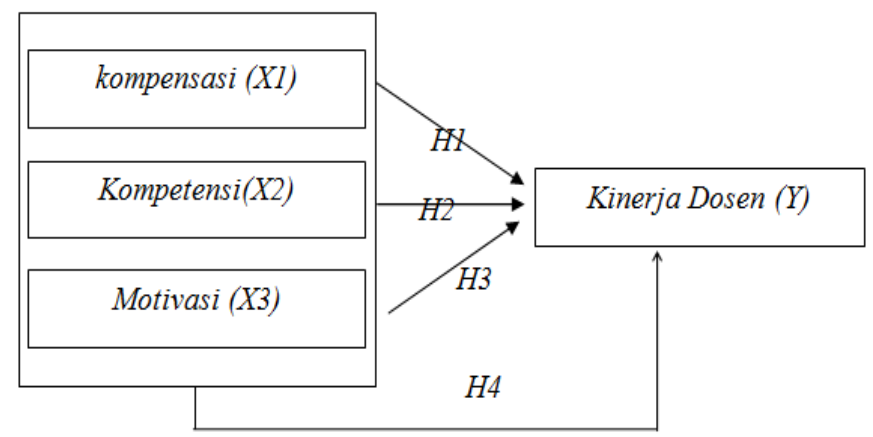

Gambar 1. Kerangka Berfikir

\subsection{Hipotesis}

Berdasarkan model penelitian di atas, maka dapat dirumuskan hipotesis penelitian sebagai berikut:

$\mathrm{H}_{1}$ : Terdapat pengaruh kompensasi terhadap kinerja dosen STMIK Royal Kisaran.

$\mathrm{H}_{2}$ : Terdapat pengaruh kompetensi terhadap kinerja dosen STMIK Royal Kisaran.

$\mathrm{H}_{3}$ : Terdapat pengaruh motivasi terhadap kinerja dosen STMIK Royal Kisaran.

$\mathrm{H}_{4}$ : Terdapat pengaruh kompensasi, kompetensi dan motivasi secara simultan terhadap kinerja dosen di STMIK Royal Kisaran. 


\section{METODOLOGI PENELITIAN}

Metode yang digunakan pada penelitian ini menggunakan metode kuantitatif dimana populasinya adalah dosen-dosen STMIK Royal Kisaran yang berjumlah sebanyak 90 orang dosen. Kemudian teknik pengambilan sampel yang digunakan adalah sampling jenuh sehingga sampel dalam penelitian ini adalah seluruh dari populasi yang diambil yang berjumlah 90 responden yang dianggap homogen. Teknik pengumpulan data menggunakan kuesioner (angket) dengan skala Likert dengan rentang skala 1-5 dengan kriteria sangat tidak setuju (STS), tidak setuju (TS), kurang setuju (KS), setuju (S) dan sangat setuju (SS). Kemudian teknik analisis data dalam penelitian ini menggunakan statistik deskriptif analisis. Sedangkan variabel yang digunakan pada penelitian ini terdiri dari variabel bebas yaitu kompensasi $\left(\mathrm{X}_{1}\right)$, kompetensi $\left(\mathrm{X}_{2}\right)$, dan Motivasi $\left(\mathrm{X}_{3}\right)$ dan variabel terikat yaitu Kinerja Dosen STMIK Royal Kisaran (Y).

\section{HASIL DAN PEMBAHASAN}

\subsection{Uji Validitas dan Reliabilitas}

Uji validitas digunakan untuk mengetahui keakuratan dan kevalidan angket penelitian yang digunakan sehingga mampu mengukur variabel kunci yang sedang diteliti (Ghozali, 2013). Uji validitas diuji dengan program SPSS 20.0 dengan melihat korelasi Pearson Correlation pada tabel Correlations untuk masing masing item pertanyaan dengan skor uji total. Dasar mengambil keputusan dari uji validitas ini dilihat dengan cara membandingan nilai $r$ hitung dengan $r$ tabel, dengan ketentuan: Jika nilai $r$ hitung $>r$ tabel, maka item kita nyatakan valid, dan sebaliknya jika $r$ hitung $<r$ tabel maka item kita nyatakan tidak valid. Untuk mendapatkan $r$ tabel diperoleh dari tabel distribusi nilai $r$ tabel pada tingkat signifikansi $5 \%$ dimana $\mathrm{N}=90$, diperoleh nilai $\mathrm{r}$ tabel $=0.207$.

Uji reliabilitas digunakan untuk mengetahui sejauh mana data dapat memberikan hasil yang relatif tidak berbeda bila dilakukan pengukuran kembali pada item yang sama, atau dapat dikatakan untuk menunjukan tingkat konsistensi angket penelitian. dengan melihat nilai alpha Cronbach's pada tabel Reliability Statistics. Menurut V. Wiratna Sujarweni (2015) dimana dasar mengambil keputusan dari uji reliabilitas ini dilihat dengan cara membandingkan nilai alpha Cronbach's. Angket dikatakan reliabel dan konsisten jika nilai alpha Cronbach's > 0.6.

\subsection{Hasil Uji Validitas dan Reliabilitas}

Tabel 1. Rekapitulasi Hasil Uji Validitas dan Reliabilitas

\begin{tabular}{lccccc}
\hline & $\begin{array}{c}\text { N=90 } \\
\text { Vumlah }\end{array}$ & \multicolumn{2}{c}{ Uji Validitas } & \multicolumn{2}{c}{ Uji Reliabilitas } \\
\cline { 5 - 6 } $\begin{array}{c}\text { Butir } \\
\text { Pertanyaan }\end{array}$ & $\boldsymbol{r}$ hitung & Keputusan & $\begin{array}{c}\text { alpha } \\
\text { Cronbach's }\end{array}$ & Keputusan \\
\hline Kompensasi $\left(\mathrm{X}_{1}\right)$ & 8 & $>0.207$ & valid & 0.631 & reliabel \\
Kompetensi $\left(\mathrm{X}_{2}\right)$ & 11 & $>0.207$ & valid & 0.625 & reliabel \\
Motivasi $\left(\mathrm{X}_{3}\right)$ & 14 & $>0.207$ & valid & 0.622 & reliabel \\
Kinerja Dosen $(\mathrm{Y})$ & 7 & $>0.207$ & valid & 0.618 & reliabel \\
\hline
\end{tabular}

Dari tabel 1 di atas dapat di interpretasikan untuk uji validitas bahwa semua variabel memiliki nilai $r$ hitung di atas nilai $r$ tabel (0.207) yang artinya seluruh butir pertanyaan dapat dikatakan valid. Sedangkan untuk uji reliabilitas seluruh variabel memiliki nilai alpha Cronbach's lebih besar dari 0.600 yang artinya bahwa semua variabel adalah konsisten atau reliable. Dengan demikian maka dapat disimpulkan bahwa semua butir item pertanyaan tersebut valid dan konsisten dalam mengukur masingmasing variabelnya. 


\subsection{Analisis Regresi Linier Sederhana}

Model persamaan regresi sederhana bertujuan untuk mengetahui pengaruh variabel independent (kompensasi, kompetensi, dan motivasi) terhadap variabel dependent (kinerja dosen). Dasar pengambilan keputusan dalam uji regresi linier sederhana didapatkan dengan cara membandingkan nilai signifikansi dengan nilai probabilitas 0,05 dimana jika nilai signifikansi $<0,05$ maka variabel independent berpengaruh terhadap variabel dependent, dan sebaliknya. Kemudian membandingkan nilai $t$ hitung dengan $t$ tabel dimana dasar pengambilan keputusannya adalah jika nilai $\mathrm{t}$ hitung $>\mathrm{t}$ tabel maka variabel independent berpengaruh terhadap variabel dependent dimana nilai $t$ tabel diperoleh dari tabel distribusi nilai t adalah sebesar 1,988.

Berdasarkan proses pengolahan data dari hasil uji analisis regresi linier sederhana menggunakan program SPSS 20.0 diperoleh hasil sebagai berikut :

\subsubsection{Hasil Uji analisis regresi linier sederhana antara variabel Kompensasi terhadap Kinerja Dosen}

Tabel 2. Model Summary Kompensasi

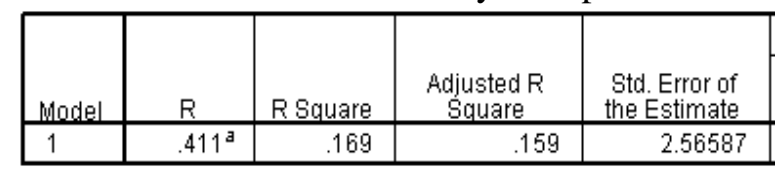

Dari tabel di atas dapat dijelaskan besarnya nilai korelasi/hubungan $(\mathrm{R})$ yaitu sebesar 0,411 dan diperoleh juga nilai koefisien determinasi ( $R$ Square) sebesar 0,169 yang mengandung pengertian bahwa pengaruh variabel kompensasi terhadap variabel kinerja dosen adalah sebesar 16,9\%.

Tabel 3. ANOVA Kompensasi

\begin{tabular}{|ll|r|r|r|r|c|}
\hline Madel & & \multicolumn{1}{c|}{$\begin{array}{c}\text { Sum of } \\
\text { Squares }\end{array}$} & \multicolumn{1}{c|}{ df } & Mean Square & F & Sig. \\
\hline 1 & Regression & 117.623 & 1 & 117.623 & 17.866 & $.000^{\mathrm{a}}$ \\
& Residual & 579.366 & 88 & 6.584 & & \\
& Total & 696.989 & 89 & & & \\
\hline
\end{tabular}

Dari tabel di atas dapat diketahui bahwa nilai $\mathrm{F}$ hitung $=17,866$ dengan tingkat signifikansi sebesar $0,000<0,05$, sehingga model regresi dapat dipakai untuk memprediksi variabel kinerja dosen atau dengan kata lain ada pengaruh variabel kompensasi terhadap variabel kinerja dosen.

Tabel 4. Coefficients Kompensasi

\begin{tabular}{|c|c|c|c|c|c|c|}
\hline \multirow[b]{2}{*}{ Mode } & & \multicolumn{2}{|c|}{ Unstandardized Coefficients } & \multirow{2}{*}{$\begin{array}{c}\begin{array}{c}\text { Standardized } \\
\text { Coefficients }\end{array} \\
\text { Beta }\end{array}$} & \multirow[b]{2}{*}{$t$} & \multirow[b]{2}{*}{ Siq. } \\
\hline & & B & Std. Error & & & \\
\hline \multirow[t]{2}{*}{1} & (Constant) & 18.884 & 2.693 & & 7.011 & .000 \\
\hline & Compensation & .343 & .081 & .411 & 4.227 & .000 \\
\hline
\end{tabular}

Dari tabel di atas diketahui nilai constant sebesar 18,884, sedangkan nilai koefisien regresi sebesar 0,343 , sehingga persamaan regresinya dapat ditulis yaitu $Y=18,884+0,343 X_{1}$. Konstanta sebesar 18,884 mengandung arti bahwa nilai konsistensi variabel kinerja dosen sebesar 18,884. Sedangkan koefisien regresi $\mathrm{X}_{1}$ sebesar 0,343 menyatakan bahwa setiap penambahan $1 \%$ nilai kompensasi, maka nilai kinerja dosen bertambah sebesar 0,343. Koefisien regresi tersebut bernilai positif, sehingga dapat dikatakan bahwa arah pengaruh variabel kompensasi terhadap kinerja dosen adalah positif.

Dari tabel koefisien di atas juga didapatkan nilai t hitung sebesar 4,227 > t tabel yaitu 1,988, sehingga dapat disimpulkan bahwa variabel kompensasi berpengaruh terhadap variabel Kinerja Dosen.

\subsubsection{Hasil Uji analisis regresi linier sederhana antara variabel Kompetensi terhadap Kinerja Dosen}

Tabel 5. Model Summary Kompetensi

\begin{tabular}{|l|r|r|r|r|}
\hline Model & \multicolumn{1}{|c|}{ R } & R Square & \multicolumn{1}{c|}{$\begin{array}{c}\text { Adjusted R } \\
\text { Square }\end{array}$} & $\begin{array}{c}\text { Std. Error of the } \\
\text { Estimate }\end{array}$ \\
\hline 1 & $.499^{3}$ & .249 & .241 & 2.43879 \\
\hline
\end{tabular}


Dari tabel di atas dapat dijelaskan besarnya nilai korelasi/hubungan (R) yaitu sebesar 0,499 dan diperoleh juga nilai koefisien determinasi (R Square) sebesar 0,249 yang mengandung pengertian bahwa pengaruh variabel kompetensi terhadap variabel kinerja dosen adalah sebesar 24,9\%.

Tabel 6. ANOVA Kompetensi

\begin{tabular}{|ll|r|r|r|r|r|}
\hline \multicolumn{1}{|l|}{} & & $\begin{array}{r}\text { Sum of } \\
\text { Model }\end{array}$ & & & & \\
\hline 1 & Rquares & df & Mean Square & F & Sig. \\
\hline & Residual & 173.593 & 1 & 173.593 & 29.187 & $.000^{3}$ \\
& 523.396 & 88 & 5.948 & & \\
\multicolumn{1}{|l|}{ Total } & 696.989 & 89 & & & \\
\hline
\end{tabular}

Dari tabel di atas dapat diketahui bahwa nilai $\mathrm{F}$ hitung $=29,187$ dengan tingkat signifikansi sebesar $0,000<0,05$, sehingga model regresi dapat dipakai untuk memprediksi variabel kinerja dosen atau dengan kata lain ada pengaruh variabel kompetensi terhadap variabel kinerja dosen.

Tabel 7. Coefficients Kompetensi

\begin{tabular}{|c|c|c|c|c|c|c|}
\hline \multirow{2}{*}{\multicolumn{2}{|c|}{ Model }} & \multicolumn{2}{|c|}{$\begin{array}{l}\text { Unstandardized } \\
\text { Coefficients }\end{array}$} & \multirow{2}{*}{$\begin{array}{c}\begin{array}{c}\text { Standardized } \\
\text { Coefficients }\end{array} \\
\text { Beta } \\
\end{array}$} & \multirow[b]{2}{*}{$\mathrm{t}$} & \multirow[b]{2}{*}{ Sig. } \\
\hline & & $B$ & Std. Error & & & \\
\hline \multirow[t]{2}{*}{1} & (Constant) & 9.575 & 3.828 & & 2.501 & .014 \\
\hline & kompetensi & .432 & .080 & .499 & 5.402 & .000 \\
\hline
\end{tabular}

Dari tabel di atas diketahui nilai Constant sebesar 9,575, sedangkan nilai koefisien regresi sebesar 0,432 , sehingga persamaan regresinya dapat ditulis yaitu $\mathrm{Y}=9,575+0,432 \mathrm{X}_{2}$. Konstanta sebesar 9,575 mengandung arti bahwa nilai konsistensi variabel kinerja dosen sebesar 9,575. Sedangkan koefisien regresi $\mathrm{X}_{2}$ sebesar 0,432 menyatakan bahwa setiap penambahan $1 \%$ nilai kompetensi, maka nilai kinerja dosen bertambah sebesar 0,432. Koefisien regresi tersebut bernilai positif, sehingga dapat dikatakan bahwa arah pengaruh variabel kompetensi terhadap kinerja dosen adalah positif.

Dari tabel koefisien di atas juga didapatkan nilai $t$ hitung sebesar 5,402 > t tabel yaitu 1,988, sehingga dapat disimpulkan bahwa variabel kompetensi berpengaruh terhadap variabel Kinerja Dosen.

\subsubsection{Hasil Uji analisis regresi linier sederhana antara variabel Motivasi terhadap Kinerja Dosen}

Tabel 8. Model Summary Motivasi

\begin{tabular}{|l|c|r|r|r|}
\hline Model & $R$ & R Square & $\begin{array}{c}\text { Adjusted R } \\
\text { Square }\end{array}$ & $\begin{array}{c}\text { Std. Error of the } \\
\text { Estimate }\end{array}$ \\
\hline 1 & $.302^{\mathrm{a}}$ & .091 & .081 & 2.68250 \\
\hline
\end{tabular}

Dari tabel di atas dapat dijelaskan besarnya nilai korelasi/hubungan $(\mathrm{R})$ yaitu sebesar 0,302 dan diperoleh juga nilai koefisien determinasi (R Square) sebesar 0,091 yang mengandung pengertian bahwa pengaruh variabel motivasi terhadap variabel kinerja dosen adalah hanya sebesar $9,1 \%$.

Tabel 9. ANOVA Motivasi

\begin{tabular}{|rl|r|r|r|r|r|}
\hline \multicolumn{1}{|l|}{} & \multicolumn{1}{|c|}{$\begin{array}{c}\text { Sum of } \\
\text { Squares }\end{array}$} & \multicolumn{1}{c|}{ df } & \multicolumn{1}{c|}{$\begin{array}{c}\text { Sean } \\
\text { Square }\end{array}$} & \multicolumn{1}{c|}{$\mathrm{F}$} & Sig. \\
\hline 1 & Regression & 63.757 & 1 & 63.757 & 8.860 & $.004^{3}$ \\
& Residual & 633.232 & 88 & 7.196 & & \\
& Total & 696.989 & 89 & & & \\
\hline
\end{tabular}

Dari tabel di atas dapat diketahui bahwa nilai $\mathrm{F}$ hitung $=8,860$ dengan tingkat signifikansi sebesar $0,004<0,05$, sehingga model regresi dapat dipakai untuk memprediksi variabel kinerja dosen atau dengan kata lain ada pengaruh variabel motivasi terhadap variabel kinerja dosen. 
Tabel 10. Coefficients Motivasi

\begin{tabular}{|c|c|c|c|c|c|c|}
\hline \multirow[b]{2}{*}{ Model } & & \multicolumn{2}{|c|}{$\begin{array}{l}\text { Unstandardized } \\
\text { Coefficients }\end{array}$} & \multirow{2}{*}{\begin{tabular}{c|}
$\begin{array}{c}\text { Standardized } \\
\text { Coefficients }\end{array}$ \\
Beta
\end{tabular}} & \multirow[b]{2}{*}{$\mathrm{t}$} & \multirow[b]{2}{*}{ Sig. } \\
\hline & & $\mathrm{B}$ & Std. Error & & & \\
\hline 1 & (Constant) & 19.941 & 3.462 & & 5.760 & .000 \\
\hline & motivasi & 179 & .060 & .302 & 2.977 & .004 \\
\hline
\end{tabular}

Dari tabel di atas diketahui nilai Constant sebesar 19,941, sedangkan nilai koefisien regresi sebesar 0,179, sehingga persamaan regresinya dapat ditulis yaitu $\mathrm{Y}=19,941+0,179 \mathrm{X}_{3}$. Konstanta sebesar 19,941 mengandung arti bahwa nilai konsistensi variabel kinerja dosen sebesar 19,941. Sedangkan koefisien regresi $\mathrm{X}_{3}$ sebesar 0,179 menyatakan bahwa setiap penambahan $1 \%$ nilai motivasi, maka nilai kinerja dosen bertambah sebesar 0,179. Koefisien regresi tersebut bernilai positif, sehingga dapat dikatakan bahwa arah pengaruh variabel motivasi terhadap kinerja dosen adalah positif.

Dari tabel koefisien di atas juga didapatkan nilai $t$ hitung sebesar 2,977 > t tabel yaitu 1,988, sehingga dapat disimpulkan bahwa variabel motivasi berpengaruh terhadap variabel Kinerja Dosen.

\subsection{Analisis Regresi Linier berganda}

Analisis regresi berganda digunakan untuk mengetahui ada atau tidaknya pengaruh secara simultan variabel bebas terhadap variabel terikat. Model persamaan regresi yang baik adalah yang memenuhi persyaratan asumsi klasik, antara lain semua data berdistribusi normal, linier, model harus bebas dari segala multikolinieritas dan terbebas dari heteroskedastisitas.

Dari analisis sebelumnya telah terbukti bahwa model persamaaan yang diajukan pada penelitian ini telah memenuhi persyaratan uji asumsi klasik sehingga model persamaan dalam penelitian ini sudah dianggap baik. Berdasarkan proses pengolahan data dari hasil uji analisis regresi linier berganda menggunakan program SPSS 20.0 diperoleh hasil sebagai berikut :

Tabel 11. Coefficients Hasil Uji Analisis Regresi Linier Berganda

\begin{tabular}{|c|c|c|c|c|c|c|}
\hline \multirow[b]{2}{*}{ Mode } & & \multicolumn{2}{|c|}{ Unstandardized Coefficients } & \multirow{2}{*}{$\begin{array}{c}\text { Standardized } \\
\text { Coefficients } \\
\text { Beta } \\
\end{array}$} & \multirow[b]{2}{*}{ t } & \multirow[b]{2}{*}{ Siq. } \\
\hline & & $\mathrm{B}$ & Std. Error & & & \\
\hline \multirow[t]{4}{*}{1} & (Constant) & 1.497 & 4.563 & & .328 & .744 \\
\hline & kompensasi & .301 & 122 & 249 & 2.462 & .016 \\
\hline & kompetensi & .310 & .087 & .358 & 3.578 & .001 \\
\hline & motivasi & .067 & .057 & .113 & 1.183 & .240 \\
\hline
\end{tabular}

Berdasarkan dari tabel di atas, maka dapat dilihat persamaan regresinya, :

$$
Y=1,497+0,301 X_{1}+0,310 X_{2}+0,067 X_{3}
$$

Dari persamaan regresi linier berganda di atas maka dapat diinterpretasikan sebagai berikut :

1. Konstanta sebesar 1,497 menyatakan bahwa jika variabel kompensasi $\left(\mathrm{X}_{1}\right)$, kompetensi $\left(\mathrm{X}_{2}\right)$ dan motivasi $\left(\mathrm{X}_{3}\right)$ dianggap konstan atau diabaikan, maka variabel kinerja dosen $(\mathrm{Y})$ sebesar 1,497.

2. Koefisien regresi Kompensasi $\left(\mathrm{X}_{1}\right)$ adalah 0,301 artinya bahwa setiap penambahan $1 \%$ nilai kompensasi, maka nilai kinerja dosen bertambah sebesar 0,301. Koefisien regresi tersebut bernilai positif, sehingga dapat dikatakan bahwa terdapat pengaruh positif variabel kompensasi secara parsial terhadap kinerja dosen STMIK Royal Kisaran.

3. Koefisien regresi Kompetensi $\left(\mathrm{X}_{2}\right)$ adalah 0,310 artinya bahwa setiap penambahan $1 \%$ nilai kompetensi, maka nilai kinerja dosen bertambah sebesar 0,310. Koefisien regresi tersebut bernilai positif, sehingga dapat dikatakan bahwa terdapat pengaruh positif variabel kompetensi secara parsial terhadap kinerja dosen STMIK Royal Kisaran.

4. Koefisien regresi Motivasi $\left(\mathrm{X}_{3}\right)$ adalah 0,067 artinya bahwa setiap penambahan $1 \%$ nilai motivasi, maka nilai kinerja dosen bertambah sebesar 0,067. Koefisien regresi tersebut bernilai positif, sehingga dapat dikatakan bahwa terdapat pengaruh positif variabel motivasi secara parsial terhadap kinerja dosen STMIK Royal Kisaran. 


\subsection{Uji Hipotesis dan Pembahasan}

\subsubsection{Uji t dan Pembahasan}

Uji t digunakan untuk mengetahui ada atau tidaknya pengaruh parsial (sendiri) yang diberikan variabel independent terhadap variabel dependent. Dasar pengambilan keputusannya dari uji t adalah dengan membandingkan nilai signifikansi terhadap nilai 0,05 serta nilai t hitung dengan nilai $t$ tabel (nilai $\mathrm{t}$ tabel $=1,988$ ), yaitu :

- Jika nilai sig $<0.05$ atau $t$ hitung $>\mathrm{t}$ tabel maka terdapat pengaruh parsial

- Jika nilai sig $>0.05$ atau $\mathrm{t}$ hitung $>\mathrm{t}$ tabel maka tidak terdapat pengaruh parsial

Pengaruh komnpensasi, kompetensi, dan motivasi secara parsial terhadap kinerja dosen dapat dilihat pada tabel 11 yaitu coefficients Hasil Uji Analisis Regresi Linier Berganda dengan menjelasan :

1. Pengaruh kompensasi Terhadap Kinerja Dosen.

Berdasarkan tabel 11 diperoleh nilai $\mathrm{t}$ hitung $>$ dari $\mathrm{t}$ tabel $(2,462>1,988)$ dengan tingkat signifikan $(0,016<0,05)$, artinya terdapat pengaruh positif dan signifikan variabel kompensasi secara parsial terhadap kinerja dosen. Dengan demikian $\mathrm{H}_{1}$ diterima dan Ho ditolak. Artinya terdapat pengaruh kompensasi secara parsial terhadap kinerja dosen di STMIK Royal Kisaran.

2. Pengaruh kompetensi Terhadap Kinerja Dosen.

Berdasarkan tabel 11 diperoleh nilai $\mathrm{t}$ hitung $>$ dari $\mathrm{t}$ tabel $(3,578>1,988)$ dengan tingkat signifikan $(0,001<0,05)$, artinya terdapat pengaruh positif dan signifikan variabel kompetensi secara parsial terhadap kinerja dosen. Dengan demikian $\mathrm{H}_{2}$ diterima dan Ho ditolak. Artinya terdapat pengaruh kompetensi secara parsial terhadap kinerja dosen di STMIK Royal Kisaran.

3. Pengaruh motivasi Terhadap Kinerja Dosen.

Berdasarkan tabel 11 diperoleh nilai $\mathrm{t}$ hitung $>$ dari $\mathrm{t}$ tabel $(1,183<1,988)$ dengan tingkat signifikan $(0,240>0,05)$, artinya tidak terdapat pengaruh positif dan signifikan variabel motivasi secara parsial terhadap kinerja dosen. Dengan demikian $\mathrm{H}_{3}$ ditolak dan Ho diterima. Artinya tidak terdapat pengaruh motivasi secara parsial terhadap kinerja dosen di STMIK Royal Kisaran.

\subsubsection{Uji F dan Pembahasan}

Uji F digunakan untuk mengetahui ada atau tidaknya pengaruh simultan (bersama) yang diberikan variabel independent terhadap variabel dependent.

Dasar pengambilan keputusannya dari uji $\mathrm{F}$ adalah dengan membandingkan nilai signifikansi terhadap nilai 0,05 serta nilai $\mathrm{F}$ hitung dengan nilai $\mathrm{F}$ tabel (nilai $\mathrm{F}$ tabel $=2,71$ ), yaitu :

- Jika nilai sig $<0.05$ atau $\mathrm{F}$ hitung $>\mathrm{F}$ tabel maka terdapat pengaruh secara simultan

- Jika nilai sig > 0.05 atau $\mathrm{F}$ hitung $>\mathrm{F}$ tabel maka tidak terdapat pengaruh secara simultan

Pengaruh kompensasi, kompetensi, dan motivasi secara simultan terhadap kinerja dosen dapat dilihat pada tabel berikut ini :

Tabel 12. ANOVA Hasil Uji Analisis Regresi Linier Berganda

\begin{tabular}{|ll|r|r|r|r|r|}
\hline Model & & Sum of & df & Mean Square & F & Sig. \\
\hline 1 & Regression & 224.871 & 3 & 74.957 & 13.654 & $.000^{3}$ \\
& Residual & 472.118 & 86 & 5.490 & & \\
& Total & 696.989 & 89 & & & \\
\hline
\end{tabular}

Dari tabel di atas dapat diketahui nilai signifikansi untuk pengaruh variabel kompensasi, kompetensi, dan motivasi secara simultan terhadap variabel kinerja dosen adalah sebesar $0.000<0.05$ dan nilai $\mathrm{F}$ hitung $13.654>2,71$, sehingga dapat disimpulkan bahwa $\mathrm{H}_{4}$ diterima dan Ho ditolak, artinya terdapat pengaruh kompensasi, kompetensi, dan motivasi secara simultan terhadap kinerja dosen di STMIK Royal Kisaran.

\subsection{Koefisien Determinasi dan Pembahasan}

Koefisien Determinasi berfungsi untuk mengetahui berapa persen pengaruh yang diberikan variabel independent secara simultan terhadap variabel dependent. 
Tabel 13. Model Summary Hasil Uji Analisis Regresi Linier Berganda

\begin{tabular}{|c|l|r|r|r|}
\hline Model & $\mathrm{R}$ & $\mathrm{R}$ Square & $\begin{array}{c}\text { Adjusted R } \\
\text { Square }\end{array}$ & $\begin{array}{c}\text { Std. Error of } \\
\text { the Estimate }\end{array}$ \\
\hline 1 & $.568^{\mathrm{a}}$ & .323 & .299 & 2.34302 \\
\hline
\end{tabular}

Berdasarkan dari tabel di atas diketahui nilai $\mathrm{R}$ square 0.323 artinya bahwa pengaruh variabel kompensasi, kompetensi, dan motivasi secara simultan atau bersama terhadap variabel kinerja dosen adalah sebesar 32,3\%. Dari data tersebut menunjukkan sekitar 32,3\% variabel Kinerja Dosen dapat dijelaskan oleh variabel kompensasi, kompetensi dan motivasi, dengan kata lain dapat dinyatakan bahwa kompensasi, kompetensi dan motivasi memberikan kontribusi terhadap kinerja dosen sebesar $32,3 \%$ sementara sisanya $67,7 \%$ dipengaruhi oleh variabel yang lain yang tidak dibahas pada penelitian ini.

\section{KESIMPULAN}

Berdasarkan dari hasil analisis data, interpretasi hasil penelitian, dan pembahasan yang telah disampaikan sebelumnya, maka dapat dikemukakan beberapa kesimpulan dari hasil penelitian ini, yaitu:

1. Variabel kompensasi berpengaruh positif dan signifikan secara parsial terhadap kinerja dosen STMIK Royal Kisaran.

2. Variabel kompetensi berpengaruh positif dan signifikan secara parsial terhadap kinerja dosen STMIK Royal Kisaran.

3. Variabel motivasi tidak berpengaruh positif dan signifikan secara parsial terhadap kinerja dosen STMIK Royal Kisaran.

4. Variabel kompensasi, kompetensi dan motivasi berpengaruh positif dan signifikan secara simultan terhadap kinerja dosen di STMIK Royal Kisaran. Kontribusi pengaruh kompetensi dan motivasi terhadap kinerja dosen adalah sebesar $32,3 \%$ sedangkan sisanya $67,7 \%$ dipengaruhi oleh variabel lainnya yang tidak masuk dalam penelitian ini. Dari kedua variabel ini, variabel yang paling dominan mempengaruhi kinerja dosen adalah variabel kompetensi.

\section{UCAPAN TERIMAKASIH}

Penelitian ini didanai oleh Deputi Bidang Penguatan Riset dan Pengembangan, Kementrian Riset dan Teknologi/ Badan Riset dan Inovasi Nasional (RISTEK-BRIN) Indonesia melalui skema Penelitian Dosen Pemula (Nomor Kontrak: B/196/M/KU.00.01/2020) untuk itu penulis mengucapkan banyak terimakasih. Selain itu penulis juga mengucapkan terima kasih kepada pihak kampus STMIK Royal Kisaran dan Yayasan Pendidikan Royal Teladan Asahan atas dukungan dan fasilitas yang diberikan dalam memudahkan proses penelitian ini.

\section{DAFTAR PUSTAKA}

1. Andayani, S. A. (2014). Hubungan Kompensasi, Kompetensi dan Motivasi dengan Kinerja Dosen di STIKes Nurul Jadid Paiton Probolinggo (Doctoral dissertation, UNS (Sebelas Maret University).

2. Fathoni, A. (2019). Organisasi dan manajemen sumber daya manusia.

3. Fatihudin, D. (2015). Metodologi Penelitian Untuk Ilmu Ekonomi, Manajemen dan Akuntansi: Dari teori ke praktek.

4. Ghozali, I. (2013). Aplikasi Analisis Multivariate Dengan Program IBM dan SPSS. In aplikasi analisis multivariate dengan program ibm spss 19 (p. 113).

5. Hasan, M. I. (2012). Pokok-pokok Materi Statistik 2 (Statistik Inferensial), Edisi 2. Jakarta: PT Bumi Aksara.

6. Hasibuan, M. S., \& Hasibuan, H. M. S. (2016). Manajemen sumber daya manusia. Bumi Aksara.

7. I'tidal, M., \& Jam'an, A. (2016). Pengaruh antara kompetensi, kompensasi, motivasi kerja dan pendidikan terhadap kinerja dosen di STIMIK AKBA Makassar. Competitiveness: Jurnal Manajemen dan Bisnis, 10(2), 16-30.

8. Hidayanto, N. (2016). Hubungan Kompensasi Kompetensi Motivasi terhadap Kinerja Dosen di Sekolah TInggi Ilmu Kesehatan Ngudia Husada Madura. JPAP: Jurnal Penelitian Administrasi Publik, 2(02). 
9. Kirana, K. C., \& Ratnasari, R. T. (2017). Evaluasi Kinerja Sumber Daya Manusia (SDM).

10. Mangkunegara, A. A. P. (2016). Manajemen sumber daya manusia perusahaan. PT. Remaja Rosdakarya.

11. Matriadi, F., \& Dalimunthe, R. F. (2018, January). Analyzing the Compensation and Competence on Senior High School Teacher's Performance through the Mediating Role of Job Motivation. In 1st Economics and Business International Conference 2017 (EBIC 2017). Atlantis Press.

12. Putri, P. (2018). Pengaruh Kepemimpinan, Kompetensi dan Budaya Organisasi Terhadap Kinerja Dosen Berbantuan Sofware SPSS. JOURNAL OF SCIENCE AND SOCIAL RESEARCH, 1(1), 86-96.

13. Rachmawati, T., \& Abdullah, S. (2013). Penilaian Kinerja Profesi Guru dan Angka Kreditnya. Yogyakarta: Gava Media.

14. Salim, M. N. Masngudi.(2012). Metodologi Penelitian Untuk Ekonomi dan Bisnis.

15. Sarboini, S., Rizal, S., Surya, J., \& Yusuf, Z. (2018). The Effect of Leadership, Compensation and Competency on Employee Performance. Jurnal Ilmiah Peuradeun, 6(2), 215-234.

16. Sujarweni, V. W. (2015). Metodologi Penelitian Bisnis \& Ekonomi

17. Wibowo, M. K. (2016). Manajemen Kinerja edisi ke 3, Jakarta: PT. Raja Grafindo 